\title{
Additional Testing Was Not Performed
}

National Cancer Institute

\section{Source}

National Cancer Institute. Additional Testing Was Not Performed. NCI Thesaurus. Code C160291.

An indication that additional tests were not performed during the study. 